\title{
Rare Feeding Behavior of Great-Tailed Grackles (Quiscalus mexicanus) in the Extreme Habitat of Death Valley
}

\author{
Stefanie Grabrucker and Andreas M. Grabrucker*
}

University Ulm, 89069 Ulm, Germany

\begin{abstract}
During the twentieth century, the Great-tailed Grackle (Quiscalus mexicanus) underwent a rapid and largescale range expansion, extending its northern limits from Texas in 1900 to 21 states in the US and 3 Canadian provinces by the end of the century. This explosive growth correlated with human-induced habitat changes. To investigate adaptations that might explain their expansion into even extreme habitats, a small number of Great-tailed Grackles were observed in Death Valley, CA. We noticed that these birds displayed a rare feeding behavior, i.e. picking dead insects from the license plates of parked vehicles. All birds used the same technique in obtaining the food and the behavior was displayed by both males and females. It was estimated that this food resource has a major contribution to the daily food intake. No other bird species sharing the same habitat showed this behavior although American crows (Corvus brachyrhynchos) had the possibility to watch the Great-tailed Grackles behavior.
\end{abstract}

Keywords: Great-tailed Grackle, Feeding behavior, Death Valley, Adaptation, License plate.

\section{INTRODUCTION}

Great-tailed Grackles (Quiscalus mexicanus) were investigated with regard to their potential to adapt and survive in extreme habitats like Death Valley, CA. The Great-tailed Grackle is a large icterid, whose range has been expanding rapidly in large-scale north and west in North America in recent years [1-8]. It reached California along the Colorado River in 1964 [9]. Most California birds are derived from the smaller subspecies $Q . m$. nelsoni, but the larger $Q . m$. monsoni also apparently occurs. It is suspected that these two forms intergraded after range expansion into the state, thus leading to a high degree of variability among California Great-tailed Grackles. The native habitat for the species is mostly grasslands, although it requires trees or cattail marshes for breeding and also prefers access to ponds $[10,11]$. It is well adapted to lawns, but also survives in cities. The diet varies widely and includes plants as well as garbage but also invertebrates and small vertebrates.

Great-tailed Grackles display a variety of feeding behaviors, including some that appear adapted to very specific circumstances, e.g., removing parasites from livestock [12], plucking food items from water [13], following behind farm machinery to collect exposed invertebrates [14], and foraging along shores turning over stones and drift-wood as well as wading for tadpoles, fish and other aquatic animals [12]. The species is tropical in origin [15], but its range expansion has not been aided by human introduction like that of the European starling (Sturnus vulgaris). During its expansion, it has also been able to occupy some areas with very extreme conditions, such as the Death Valley.

The climate in Death Valley is one of the most extreme on earth. In summer 2001, 154 consecutive days were

\footnotetext{
*Address correspondence to this author at the 2376 Lucretia Ave. Nr. 2, San Jose, CA 95122, USA; Tel: +1 (650) 7967457; E-mail: andreas.grabrucker@uni-ulm.de
}

recorded with a temperature above $37,8^{\circ} \mathrm{C}$. The summer of 1996 had 40 days over $48,9^{\circ} \mathrm{C}$, and 105 days over $43,4^{\circ} \mathrm{C}$ [16]. Heat exposure significantly decreases live weight gain, feed efficiency, and carcass weight in birds like quails $[17,18]$ and most likely has similar effects on other species. It is thus reasonable to assume that the Great-tailed Grackles underwent adaptations to survive und spread at Death Valley. Since the species has only been present for 30 years, such adaptations most likely occurred on a behavioral level. Here we report Great-tailed Grackles picking dead insects from license plates of parked vehicles, a feeding behavior that may have contributed to their success in populating Death Valley. Although Schardien and Jackson [19] described the foraging of Boat-tailed Grackles (Quiscalus major) at car radiators in Florida in 1977, the behavior has not been investigated closer and quantified before.

\section{METHODS}

Great-tailed Grackles were located during irregular visits near Furnace Creek Ranch, Death Valley, CA (36 ${ }^{\circ} 27^{\prime}$ 24,57" N, $116^{\circ} 51^{\prime} 56,45^{\prime \prime} \mathrm{W}$, elev -50m) in August 2009 (Fig. 1). Furnace Creek consists of a golf course, date plantation and a resort hotel surrounded by the Death Valley desert. The climate is generally sunny, dry and clear with summer temperatures commonly above $48,5^{\circ} \mathrm{C}$. There are well-marked temperature differences between day and night and colder months from November through March. Nevertheless Death Valley is one of the hottest and driest places on earth with an average annual rainfall at Furnace Creek of less than $4.2 \mathrm{~cm}$ for the recent 50 -year period.

At Death Valley Furnace Creek Ranch, small numbers of Great-tailed Grackles are present throughout the year. We observed Great-tailed Grackles at areas frequently occupied by visitors with cars. Our observations were mainly conducted at the parking lot of Furnace Creek Ranch. Four or five birds were present continuously throughout the 

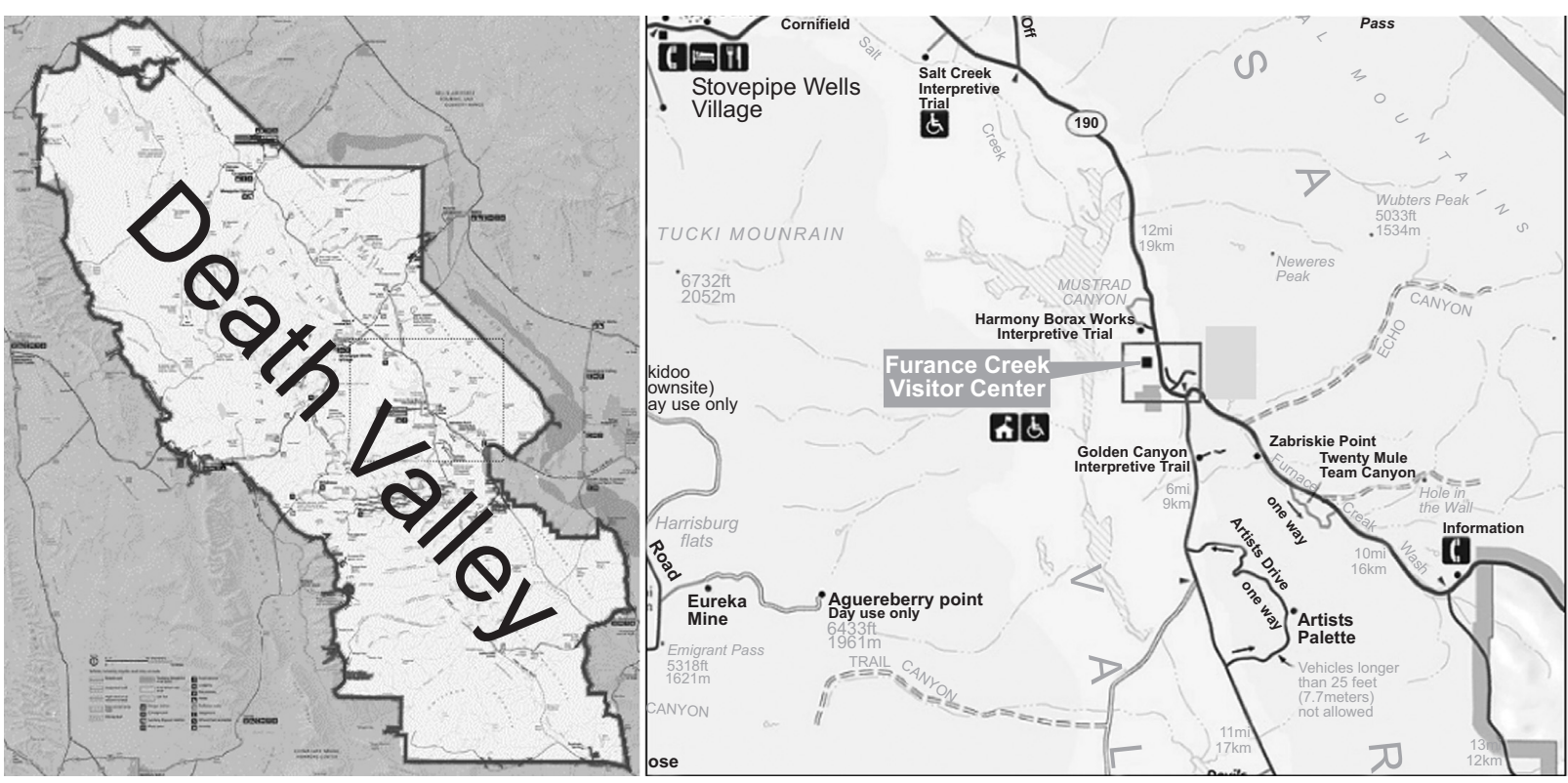

Fig. (1). Overview over Death Valley National Park, CA and the observational sites.

Great-tailed Grackles were observed near Furnace Creek Ranch, Death Valley, CA (36 ${ }^{\circ} 27^{\prime} 24,57^{\prime \prime}$ N, 116 51' 56,45" W, elev -50m). Modified from www.nps.gov.deva

observation periods, all of them picking dead insects form license plates. 1-hr focal observation periods were performed 3 times during daylight hours on 3 days. 3 animals were recorded and the time spent for the behavior as wells as the number of picks was measured. The mean number of insects per hour and bird were quantified as well as the total time spent on the behavior. The average number and duration of license plate picking per vehicle was recorded as well as the overall time spent on picking. The whole sequence of individually discernible steps of the behavior from aiming until getting the insect was taken as well as the time spent through walking to nearby cars, if it was directly followed through another picking behavior. Since the birds showed nearly no tendency to flee upon approaching, observation was performed without auxiliaries.

\section{RESULTS}

Great-tailed Grackles were observed picking dead insects from license plates (Fig. 2). This was performed in a rather
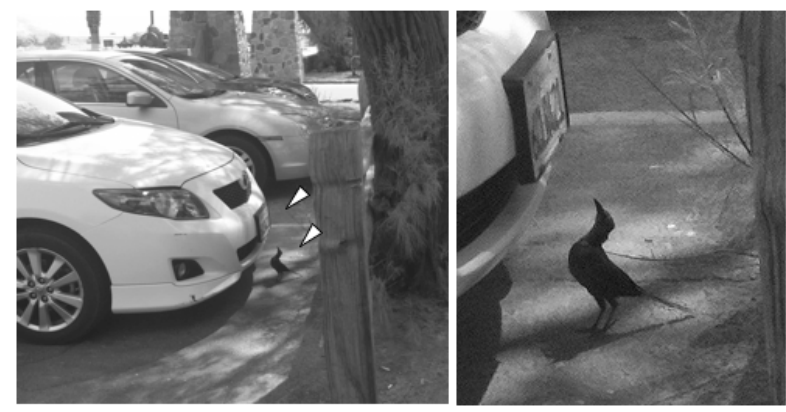

Fig. (2). A female Great-tailed Grackle ready to pick dead insects from a license plate at Death Valley

The movement consists of first aiming (shown), followed by picking together with a small jump and reaching out with the head, while spreading the wings briefly. stereotypic manner, first aiming at the insect for about a second, then picking together with a small jump and reaching out with the head, while spreading the wings briefly. The insect was taken in nearly $100 \%$ of attempts.

Therefore, to assess the time spent on this behavior and to approximate the food intake gained through this, the mean number of insects per hour and bird were quantified as well as the total time spent on the behavior (Fig. 3). During the $1 \mathrm{~h}$ of observation, cars were present all the time and continuously changing so that a new food resource was provided all the time. The whole process of aiming until getting the insect was recorded as well as the time spent through walking to nearby cars, if it was directly followed through another picking behavior. In total, averaging three days with three times one hour per day and 3 animals per hour, the Great-tailed Grackles performed 46,8 picks (+-9,6) and spent 20,4 min (+-6 $\mathrm{min}$ ) time on the behavior (Fig. 3). The remaining time was not used for food uptake. Thus, during at least three hours per day one third of the time is spent on this feeding behavior and the insects on the license plates are the only food source during this time. Since the birds continued the behavior and stayed at the Furnace Creek Ranch parking lot after the end of the observation period, it is most likely that the behavior is performed more than three hours per day.

\section{DISCUSSION}

Some bird species in Death Valley are abundant despite pressures of extreme weather conditions and seem to benefit from habitat disturbance like visiting tourists, while others are experiencing severe population declines. Verdins (Auriparus flaviceps) were previously found at Furnace Creek [20], but have been absent after the population declined in the early 1970s [21,22]. In contrast the first Great-tailed Grackles appeared in California only in 1964 
Mean Average of Number of picks per hour after $3 \times 1 \mathrm{~h}$ observation of 3 birds

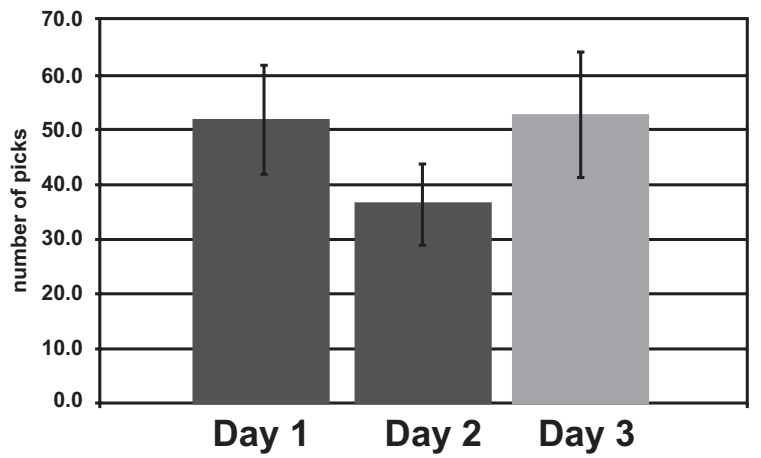

Mean Average of time per hour after $3 \times 1 \mathrm{~h}$ observation of 3 birds spent for the behavior

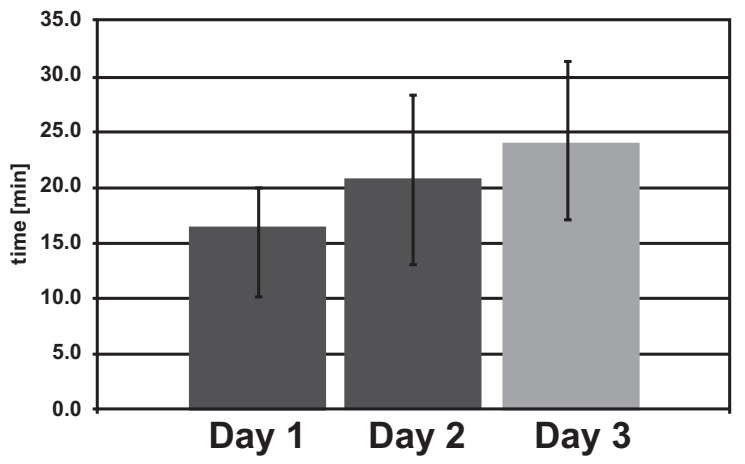

Fig. (3). Time spent on the described behavior and number of insects picked per hour by Great-tailed Grackles.

1-hr focal observation periods were performed 3 times during daylight hours on 3 days. 3 animals were recorded and the time spent for the behavior as wells as the number of picks was measured. $34 \%$ of the total time was attributed to picking insects from license plates. During that time an average of 46,8 arthropods was picked.

and successfully populated Death Valley. The potential to use novel or unusual food items may provide advantages for animals invading new environments [23]. It was shown by Sol and Lefebvre [24] that there are evolutionary characteristics like behavioral flexibility that make some species more successful than others at invading new communities. In birds, the innovation rate is associated with the ability to establish themselves in new regions [25]. The frequency of foraging innovations reported in literature correlates with the brain size of birds [26] and behavioral flexibility enables birds to respond rapidly to novel environmental conditions and presumably allows them to exploit a wider variety of ecological systems [27]. Living in groups is positively correlated with enlarged brain size [28]. Once an individual displays a new behavior, it can spread socially and become part of the behavioral repertoire of the whole population $[29,30]$. Extra foraging skills may provide an alternative food source that in some periods may play an important role and increase individual fitness. Similar to a rare feeding behavior of Great Grey Shrikes (Lanius excubitor) observed by Antczak et al. in some individuals of the species, it might be possible that individual experience plays a crucial role [31].

Great-tailed Grackles display a high degree of variation between races in size as well as color and tail length. They are also sexually dimorph [32] and therefore, there arise identification problems in the field because the spectrum of variation is not well known. The shape and size of the investigated Great-tailed Grackles in Death Valley is most likely $Q . m$. monsoni, although they showed a long tail and dark females, leaving the possibility for a interbreeding with Q. m. nelsoni open [33]. Our studies could show that the Great-tailed Grackles adapted to the new habitat of Death Valley through a previously undescribed eating behavior. Since their original diet usually consist of arthropods, small vertebrates and plant matter it is reasonable that through the absence of most of these food resources due to the extreme habitat, dead insects of license plates as well as garbage from tourists at Furnace Creek Ranch has a major contribution to the daily food intake. Although no data for the minimum daily food consumption for Great-tailed Grackles is available, Teather and Weatherhead could show that the average number of food items for nestlings between 8 and 11 days was 66/57 (males/females). These food items were mainly arthropods. Furthermore they estimated $1182 \mathrm{~kJ}$ for females weighting $70 \mathrm{~g}$ and $1400 \mathrm{~kJ}$ per male (approx. $115 \mathrm{~g}$ weight) [34]. Since the energy content of dead insect greatly varies dependent upon their state, it is hard to quantify the caloric intake received through the behavior. Nevertheless with an average of 46,8 insects per hour, the needs of a nestling would have already been mostly fulfilled (Fig. 3). Interestingly, other birds like American crows (Corvus brachyrhynchos) or European starlings that are also well known to use human resources to survive were not observed to show the behavior of picking insects from license plates, although they were found at the same place and were even able to watch the Great-tailed Grackles. Nevertheless it is possible that they show the same behavior on other places or other daytimes, although they never attempted to do so in presence of the Great-tailed Grackles and thus were not frightened away by them. The behavior was displayed by female as well as male Great-tailed Grackles and performed in a stereotypic movement. In contrast to the described behavior of Boat-tailed Grackles in Florida [19], only the license plate was used through the birds as insect resource and no picking on other parts of cars like front bumpers and radiators that also contained dead animals was observed. This was not due to the better visibility, because even at white cars the license plate was the only place for picking insects. It is more likely that the flat surface of license plates facilitates the picking of the prey. Since all present Greattailed Grackles showed the behavior one can only speculate about the origin. Obviously, the size of the bird and its bill predetermined its ability to do so. Since the size of the population of the species at Furnace Creek is not known, it is difficult to investigate if a significant proportion of the population of Great-tailed Grackles shows the behavior. Although, the observed birds were not always the same individuals, one might only speculate how many members of the local population are capable to perform the behavior. Although it might account for a major food source of the birds, it is reasonable that it is substituted by other food sources like garbage cans or foraging on golf course fairways. 
The unequal impacts of human disturbance on different bird species is likely a cause of the specific features of each species, like habitat specificity, reproductive rates, territory size and the ability to adapt. Continuing studies on the ability to innovate new strategies to survive and populate new habitats will further reveal, why some species spread, while others are undergoing population declines especially in regard of human disturbance of previous unpopulated regions on earth.

\section{REFERENCES}

[1] Arnold KA, Folse LJJ. Movements of the great-tailed grackle in Texas. Wilson Bull 1977; 89(4): 602-8.

[2] Dinsmore JJ, Dinsmore SJ. Range expansion of the great-tailed grackle in the 1900s. J Iowa Acad Sci 1993; 100(2): 54-9.

[3] Elder DH. Great-tailed grackle new to Ontario Canada. Ontario Birds 1988; 6(1): 28-31.

[4] Faanes CA, Norling W. Nesting of the great-tailed grackle ouiscalus-mexicanus in Nebraska USA. Am Birds 1981; 35(2): 148-9.

[5] Scheuering EJ, Ivey GL. First nesting record of the great-tailed grackle in oregon. Wilson Bull 1995; 107(3): 562-3.

[6] Stepney PHR. First recorded breeding of great-tailed grackle in Colorado. Condor 1975; 77(2): 208-10.

[7] Wehtje W. The range expansion of the great-tailed grackle (ouiscalus mexicanus gmelin) in North America since 1880. J Biogeogr 2003; 30(10): 1593-607.

[8] White CM, Frost HH, Shirley DL, Webb GM, Porter RD. Bird distributional and breeding records for southeastern idaho Utah and adjacent regions USA. Great Basin Naturalist 1983; 43(4): 717-27.

[9] McCaskie G, Stallcup R, DeBenedictis P. Notes on the distribution of certain icterids and tangers in California. Condor 1966; 68: 5957.

[10] Jaramillo A, Burke P. New world blackbirds. Princeton NJ.: Princeton Uni Press 1999.

[11] Peterson R. Western birds. Boston MA: Houghton Mifflin Co. 1990.

[12] Skutch AF. Life histories of central american birds. Pac Coast Avifauna 1954; 31: 1-448

[13] Griscom L. The distribution of bird-life in Guatemala. Bull Am Mus Nat Hist 1932; 64: 1-439.

[14] Rappole JH, Kane AH, Flores RH, Tipton AR, Koerth N. Seasonal variation in habitat use by great-tailed grackles in the lower Rio Grande Valley. ninth great plains wildlife damage control workshop proceedings. In: Bjøgstad AJ, Uresk DW, Hamre RH, Tech. Coords. USDA For. Serv Gen Tech Rep 1989; RM-171: pp. 138-41.

[15] Haemig PD. Aztec emperor auitzotl and the great-tailed grackle. Biotropica 1978; 10(1): 11-7.
[16] National Park Service, US. Department of the Interior, Death Valley, CA. Available from: http://www.nps.gov/deva/ planyourvisit/upload/Weather\%20and\%20Climate.pdf [accessed 09/15/2009]

[17] Sahin K, Ozbey O, Onderci M, Cikim G, Aysondu MH. Chromium supplementation can alleviate negative effects of heat stress on egg production, egg quality and some serum metabolites of laying Japanese quail. J Nutr 2002; 132: 1265-1268.

[18] Sahin N, Onderci M, Sahin K, Cikim G, Kucuk O. Magnesium proteinate is more protective than magnesium oxide in heatstressed-quail. J Nutr 2005; 135(7): 1732-7.

[19] Schardien BJ, Jackson JA. Foraging of boat-tailed grackles at car radiators. Florida Field Naturalist 1978; 6(1): 20.

[20] Grinnell J. Further observations upon the bird life of death valley. Condor 1934; 36: 67-72.

[21] Garrett K, Dunn J. Birds of southern California: status and distribution. Artisian Press: Los Angeles, California 1981.

[22] Small A. California birds: their status and distribution. Ibis Publishing Company: Vista, California 1994; p. 180.

[23] Sol D, Duncan RP, Blackturn TM, Cassey P, Lefebvre L. Big brains, enhanced cognition, and response of birds to novel environments. Proc Natl Acad Sci USA 2005; 102: 5460-5.

[24] Sol D, Lefebvre L. Behavioural flexibility predicts invasion success in birds introduced to New Zealand. OIKOS 2000; 90: 599-605.

[25] Lefebvre L, Reader SM, Sol D. Brains, innovations and evolution in birds and primates. Brain Behav Evol 2004; 63: 233-46.

[26] Overingtona SE, Morand-Ferron J, Boogerta NJ, Lefebvre L. Technical innovations drive the relationship between innovativeness and residual brain size in birds. Anim Behav 2009; 78 : 1001-10.

[27] Wyles JS, Kunkel JG, Wilson AC. Birds, behavior, and anatomical evolution. Proc Natl Acad Sci USA 1983; 80(14): 4394-7.

[28] Dunbar RIM. The social brain hypothesis. Evol Anthropol 1998; 6: 178-90.

[29] Lefebvre L, Bouchard J. Social learning about food in birds. The biology of traditions: models and evidence. In: Fragaszy DM, Perry S, Eds. Cambridge University Press: Cambridge 2003; pp. 94-126.

[30] Boogert NJ, Reader SM, Hoppitt W, Laland KN. The origin and spread of innovations in starlings. Anim Behav 2008; 75: 1509-18.

[31] Antczak M, Hromada M, Tryjanowski P. Frogs and toads in the food of the great grey shrike (Lanius excubitor): larders and skinning as two ways to consume dangerous prey. Anim Biol 2005; 55(3): 227-33.

[32] Teather KL. Sexual size dimorphism in great-tailed grackles: the costs of sons and daughters. Carleton University (Canada): Canada 1988.

[33] Wehtje W. The great-tailed grackle (Quiscalus mexicanus Gmelin) in the western USA: range expansion and secondary contact between subspecies. University of California, Riverside: United States; California 2004.

[34] Teather KL, Weatherhead PJ. Sex-specific energy requirements of great-tailed grackle (Quiscalus mexicanus) nestlings. J Anim Ecol 1988; 57(2): 659-68.

(C) Grabrucker and Grabrucker; Licensee Bentham Open.

This is an open access article licensed under the terms of the Creative Commons Attribution Non-Commercial License (http://creativecommons.org/licenses/by$\mathrm{nc} / 3.0 /$ ), which permits unrestricted, non-commercial use, distribution and reproduction in any medium, provided the work is properly cited. 